Univerzitet u Beogradu
Poljoprivredni fakultet
Institut za poljoprivrednu tehniku
Naučni časopis
POLJOPRIVREDNA TEHNIKA
Godina XLV
Broj 1,2020 .
Strane: $20-37$

UDK: 631.6:631.536

\title{
DRYING CHARACTERISTICS OF YAM VARIETIES: A COMPARATIVE ANALYSIS
}

\author{
Chineze G. Okeke ${ }^{1 *}$, B.E. Eje ${ }^{1}$, P.C. Eze ${ }^{1}$ \\ Department of Agricultural and Bioresource Engineering, Faculty of Engineering, \\ Enugu State University of Science and Technology (ESUT), Enugu, Nigeria
}

\begin{abstract}
The drying characteristics of five yam varieties (white yam, purple yam, three leaves yam, water yam and yellow yam) were investigated under three drying methods, using electric oven, natural sun and solar dryer). The yam tubers were washed, hand-peeled, sliced to size of $10 \mathrm{~mm}$ thickness and each variety was divided into three sets for use at the three different drying methods. They were dried to a constant weight at a temperature of $33^{\circ} \mathrm{C}$. The drying was repeated 6 times and the average of the weights taken.

In all the drying methods the yam varieties had moisture ratio ranges of $0.21-0.08 \%$ and the drying rates of $20 \% / \mathrm{hr}-10 \% / \mathrm{hr}$ for solar dryer, $16 \% / \mathrm{hr}-10.1 \% / \mathrm{hr}$ for oven dryer and $23 \% / \mathrm{hr}-19.05 \% / \mathrm{hr}$ for sun dryer while constant weight was attained at 180 to 300 minutes in oven- dried samples, 390 to 480 minutes for solar-dried samples and 780 to 960 minutes for sun-dried samples. In oven drying method purple yam dried faster (180 mins) followed by yellow yam (240 mins) and white yam (300 mins). Drying was accomplished in two days under sun drying method with three leave yam, purple yam and yellow yam having the same least time of drying while the white yam and water yam had the same highest drying period.
\end{abstract}

Key words: Yam varieties, Drying, Drying methods, Solar, Sun, Oven.

\footnotetext{
* Correspondeng author. E-mail address. chinezeglory@yahoo.com
} 


\section{INTRODUCTION}

Yam is a tuberous crop with great economic value in the whole world, especially in the tropical regions of West Africa. It belongs to the family Dioscoreaceae and genus Dioscorea that produce tubers and bulbils or rhizomes.

Yams are widely distributed all over the world, but with greater circulation in the tropical regions where they form important crops and food sources for tropical countries in West Africa, West Indies, East African, America, China, Japan, Philippines, Madagascar, Southeast Asia, South Caribbean, Malaysia, South Pacific Island, Korea and Papua New Guinea (Agwu and Alu, 2005). In most of these countries, yam constitute good portion of the sources of dietary calories of their population, while in some countries like Japan and China, yams contribute significantly to their industrial raw materials, especially in the areas of pharmaceutical and brewery industries. In the recent past, the production of non grain ethanol as an alternative to fuel using yam, cassava and potato (Louis, 2008) has been embraced by technologically developed countries of Asia. According to FAO (2008), the trend of global yam production shows that Africa accounts for about $96 \%$ of world production of yam, with Nigeria alone being responsible for nearly three quarters of the world total production; $73.8 \%$ of African total production, 35.017million metric tons/year (IITA, 2013).

Most of the world and African yam production is concentrated in the "yam belt" starting from Cote d'Ivoire, through Ghana then Togo, Cameroon and Nigeria, where yam is not just a food security crop but an indigenous food crop that is harmonized into socio-cultural lives of the people (IITA 2008).

Yam tubers are among the major tuber crops making impact in the Nigeria economy, in terms of capacity and value. They are processed into flours for making livestock feed and in industrial starch production (Idumah et al., 2014; Agriculture Nigeria, 2014). Yams occupy significant position in the food combination of many homes, especially the middle and upper class family of the Nigerian society where consumption of pounded yam is considered classic.

The ancient process of making pounded yam which requires pounding with mortar and pestle is extremely tedious and sometimes unhealthy. The rise in population of middle class family and increase in health consciousness among the people is making the conventional method of making pounded yam in Nigeria outdated as people are now moving from the use of mortar and pestle to modern hygienically processed yam flour; which is easy to prepare and saves time (African - foodie, 2012). The critical stage in yam flour processing is the drying stage because the quality of flour depends to a large extent on the drying method and time. Longer time exposes the yam slides to extraneous contaminants such as microbial particles and particulate matters, while the drying method may have effects on the stability of the active nutrient components. The need to find the ideal drying methods that will minimize exposure to extraneous contaminants, conserve nutrients composition and produce yam flour of wide acceptability is the desire of food engineers, technologists and allied scientists. This study was designed to address this. 
The aim of the study was to determine which of the three drying methods would provide the required data that would guide food manufacturers, processors and engineers in selection of engineering process design, instrumentation and storage stability of yam to meet the wider acceptability to the industrialists and consumers.

\section{MATERIALS AND METHOD}

\subsection{Sample collection and preparation}

Five varieties of yam tubers namely; white yam (Dioscorea rutundata), purple yam (Dioscorea alata), yellow yam (Dioscorea cayenensis), three leaves yam (Dioscorea bulbifera) and water yam (Dioscorea alata) were used for the study. They were obtained from Anambra State Agricultural Development Programme (ANADEP) farm in December 2016 at harvest moisture content range from 56.8 to $65 \% \mathrm{wb}$. The yam tubers were washed, hand-peeled and sliced to range of 10 to $15 \mathrm{~mm}$ thickness.

\section{2: Determination of the drying characteristics}

Each sliced variety of the yam tubers were divided into three sets for use at three different drying methods (oven dryer, sun dryer and solar dryer). Equal weight ( $2 \mathrm{~g}$ ) of slice from each yam varieties was subjected to oven-drying using electric oven dryer (model LOA 1805, Munich Germany), solar-drying using solar dryer (locally fabricated with thermal efficiency of $46.77 \%$, percentage energy loss of $16.73 \%$ ) and open airdrying using natural sun dryer. A stable drying condition of $33^{\circ} \mathrm{C}$ at air velocity of 1.85 $\mathrm{m} / \mathrm{s}$ and relative humidity of $20.6 \%$, for oven method was achieved in the oven before loading the first set of yam samples.

The drying temperature in solar dryer was controlled to $33^{\circ} \mathrm{C}$ at $1.45 \mathrm{~m} / \mathrm{s}$ air velocity and Sun drying was done between 30 to $35^{\circ} \mathrm{C}$ ( average $33^{\circ} \mathrm{C}$ ) at air velocity of $1.25 \mathrm{~m} / \mathrm{s}$, and relative humidity of $30.6 \%$. The microclimatic features (temperature, humidity and air speed were monitored using thermocouple for solar dryer, whirling hygrometer and vane anemometer for the relative humidity and speed of the air in sun dryer respectively and airflow meter for the air speed in the oven were determined according to standard methods. The same drying condition was maintained in all the drying methods for ease of comparison. The samples were removed and weighed every 30 minutes to record moisture loss data until constant weight was achieved in each case (Sinjh, 2001). The initial moisture content of the samples in (wb) was determined using moisture meter.

Moisture content at any time of drying was determined using equation:

$$
\mathrm{MC} t=\frac{w t-(w i \times d m)}{w t}=\frac{w t-w d}{w t},
$$

Where:

$\mathrm{MC}_{\mathrm{t}}=$ moisture content $(\% \mathrm{wb})$ at time $\mathrm{t}$;

$\mathrm{wt}=$ weight of sample at a time;

wi $=$ initial moisture content $(\% \mathrm{wb})$;

$\mathrm{d}_{\mathrm{m}}=$ dry matter ratio,

$\mathrm{wd}=$ Final moisture content. 
As the drying progressed, the moisture contents of the samples were measured using gravimetric method (Association of Official Analytical Chemists, AOAC 2000). The experiment was done 6 times and average taken. The other drying characteristics were determined mathematically as derivatives from the moisture content.

\section{Drying time}

The drying rate was determined using the expression:

Drying rate, $\mathrm{hr}^{-1}=\frac{d M}{d \theta}$, where $\mathrm{M}=$ Moisture content of grain at any time $\theta, \theta=$ Time in hr.

\section{Moisture ratio}

The moisture ratio was calculated using equation:

$\underline{\mathrm{MR}}=\frac{M_{t}-M_{e}}{M_{o}-M_{e}}$, simplified to equation

$\mathrm{MR}=\frac{M t}{M o}$,

Where:

$\mathrm{MR}=$ moisture ratio $(-)$,

$\mathrm{M}_{\mathrm{t}}=$ Moisture content at time, $\mathrm{t}(\% \mathrm{wb})$

$\mathrm{M}_{\mathrm{e}}=$ equilibrium moisture content (\% wb),

$\mathrm{M}_{\mathrm{o}}=$ initial moisture content $(\% \mathrm{wb})$

\section{Equilibrium moisture content and equilibrium relative humidity}

Equilibrium moisture content was determined according to Ndirika and Onwualu (2016) and the corresponding relative humidity was equilibrium relative humidity.

$$
\mathrm{Me}=\frac{M-M o e^{-k \theta}}{1-e^{-k \theta}},
$$

Where:

$\mathrm{Me}=$ equilibrium moisture content, $\%$ (wb)

$\mathrm{M}=$ Moisture content at any time, $\%(\mathrm{wb}), \theta=$ Time, hr.

Mo = initial moisture content, \% (wb),

$\mathrm{K}=$ drying constant $\left(\mathrm{h}^{-1}\right)=\ln \mathrm{MR} / \mathrm{t}$

$\mathrm{t}=$ time $(\mathrm{h}), \mathrm{MR}=$ moisture ratio

The data acquired were subjected to descriptive statistics using statistical package SPPS version 7, Chicago and presented in tables and line graphs were drawn using Microsoft Excel 2007. 


\section{RESULTS AND DISCUSSION}

The results are presented in tables 1-7 and figures 1-13. Drying characteristics at different heating methods at the same temperature are represented in tables 1-3, while the moisture ratios of the five yam varieties at the same temperature using oven method is represented in table 4. Comparative moisture behaviours are represented in figures 1 and 2 , while the time effects on drying rates on moisture are represented in figures 3 to 9. Moisture ratios of the yam varieties are represented in figures 10-13.

Table 1 represents the drying characteristics of yam varieties dried using oven drying method at $33^{\circ} \mathrm{C}$. At about $100 \mathrm{mins}$, the drying rate decreased as time progressed. The yellow yam had the highest average drying rate $(0.91-0.01 \% / \mathrm{min}$ with an average drying rate of $0.41 \% / \mathrm{min})$ followed by water yam $(0.90-0.01 \% / \mathrm{min}$ with an average drying rate of $0.39 \% / \mathrm{min})$, three leaves yam $(0.88-0.01 \% / \mathrm{min}$ and an average drying rate of $0.38 \% / \mathrm{min})$, purple yam $(0.82-0.01 \% / \mathrm{min}$ with an average drying rate of $0.36 \% / \mathrm{min})$ and least was the white yam $(0.78-0.02 \% / \mathrm{min}$, with an average drying rate of $0.37 \% / \mathrm{mins})$. The standard deviation of the drying rate obtained for the yam varieties at $33^{\circ} \mathrm{C}$ range from $\pm 0.38- \pm 0.46$; which is an indication that the values obtained for the drying rate didn't deviate much from the mean values. The average drying rate obtained for the yam varieties fall within the range obtained by Shuaeeb and Joshua (2013) for poundo yam. It took a total time range of 240- 300 mins to bring all the yam varieties to a constant weight level fit for milling.

\begin{tabular}{|c|c|c|c|c|c|c|c|c|c|c|}
\hline \multirow{2}{*}{$\begin{array}{l}\text { Drying } \\
\text { time } \\
\text { (mins) }\end{array}$} & \multicolumn{2}{|c|}{ White yam } & \multicolumn{2}{|c|}{ Three leaves yam } & \multicolumn{2}{|l|}{$\begin{array}{c}\text { Purple } \\
\text { yam }\end{array}$} & \multicolumn{2}{|c|}{ Water yam } & \multicolumn{2}{|c|}{ Yellow yam } \\
\hline & $\begin{array}{c}\text { Drying } \\
\text { rate, } \\
\% / \text { min }\end{array}$ & $\begin{array}{c}\text { M.C, \% } \\
(w b)\end{array}$ & $\begin{array}{c}\text { Drying } \\
\text { rate, } \\
\% / \mathrm{min} \\
\end{array}$ & $\begin{array}{c}\text { M.C, \% } \\
(w b)\end{array}$ & $\begin{array}{c}\text { Drying } \\
\text { rate, } \\
\% / \mathrm{min}\end{array}$ & $\begin{array}{c}\text { M.C, \% } \\
(w b)\end{array}$ & $\begin{array}{c}\text { Drying } \\
\text { rate, } \\
\% / \mathrm{min}\end{array}$ & $\begin{array}{c}\text { M.C, \% } \\
(w b)\end{array}$ & $\begin{array}{c}\text { Drying } \\
\text { rate,\%/min }\end{array}$ & $\begin{array}{c}\text { M.C, \% } \\
(w b)\end{array}$ \\
\hline 0.00 & - & 65.00 & - & 58.3 & - & 50.71 & - & 63.40 & - & 56.8 \\
\hline 30 & 0.780 & 41.50 & 0.880 & 32.00 & 0.82 & 36.02 & 0.90 & 36.30 & 0.910 & 29.40 \\
\hline 60 & 0.770 & 23.00 & 0.810 & 13.01 & 0.81 & 8.01 & 0.89 & 20.14 & 0.900 & 10.18 \\
\hline 90 & 0.110 & 13.50 & 0.090 & 4.50 & 0.06 & 3.08 & 0.07 & 10.58 & 0.80 & 3.22 \\
\hline 120 & 0.50 & 8.00 & 0.20 & 2.50 & 0.09 & 2.06 & 0.06 & 4.81 & 0.70 & 2.19 \\
\hline 150 & 0.20 & 5.00 & 0.12 & 1.30 & 0.07 & 1.05 & 0.05 & 3.32 & 0.09 & 1.21 \\
\hline 180 & 0.08 & 3.00 & 0.05 & 1.23 & 0.04 & 1.04 & 0.04 & 2.05 & 0.08 & 1.14 \\
\hline 210 & 0.06 & 2.00 & 0.03 & 1.10 & 0.03 & 1.03 & 0.03 & 1.55 & 0.07 & 1.82 \\
\hline 240 & 0.03 & 1.50 & 0.02 & 1.08 & 0.02 & 1.02 & 0.002 & 1.50 & 0.05 & 1.08 \\
\hline 270 & 0.02 & 1.05 & 0.01 & 1.06 & 0.01 & 1.02 & 0.001 & 1.40 & 0.02 & 1.08 \\
\hline 300 & 0.02 & 1.05 & 0.01 & 1.06 & 0.01 & 1.02 & 0.001 & 1.40 & 0.001 & 1.08 \\
\hline Mean \pm S.D & \multicolumn{2}{|c|}{$0.37 \pm 0.38$} & \multicolumn{2}{|c|}{$0.38 \pm 0.44$} & \multicolumn{2}{|c|}{$0.36 \pm 0.41$} & \multicolumn{2}{|c|}{$0.39 \pm 0.45$} & \multicolumn{2}{|c|}{$0.41 \pm 0.46$} \\
\hline
\end{tabular}

S.D = Standard deviation 
Table 2 represents the drying characteristics of yam varieties dried using solar drying method at $33^{\circ} \mathrm{C}$. White yam recorded a drying rate range of $0.42-0.01 \% / \mathrm{min}$ while the three leaves yam had $0.53-0.02 \% / \mathrm{min}$, purple yam $0.92-0.01 \% / \mathrm{min}$, water yam $0.51-0.01 \% / \mathrm{min}$ and yellow yam $0.56-0.01 \% / \mathrm{min}$. The white yam, three leaves, purple yam, water yam and yellow yam recorded average drying rate of $0.21,0.26,0.46$, 0.27 and $0.28 \% / \mathrm{min}$ respectively.

Table 2. Drying characteristics of yam varieties dried at $33^{\circ} \mathrm{C}$ using solar drying method

\begin{tabular}{|c|c|c|c|c|c|c|c|c|c|c|}
\hline \multirow{2}{*}{$\begin{array}{l}\text { Drying } \\
\text { time } \\
\text { (mins) }\end{array}$} & \multicolumn{2}{|c|}{ White yam } & \multicolumn{2}{|c|}{ Three leaves yam } & \multicolumn{2}{|l|}{$\begin{array}{l}\text { Purple } \\
\text { yam }\end{array}$} & \multicolumn{2}{|c|}{ Water yam } & \multicolumn{2}{|c|}{$\begin{array}{l}\text { Yellow } \\
\text { yam }\end{array}$} \\
\hline & $\begin{array}{c}\text { Drying } \\
\text { rate } \\
\% / \text { min }\end{array}$ & $\begin{array}{c}M . C \\
\% \\
(d b)\end{array}$ & $\begin{array}{l}\text { Drying } \\
\text { rate } \\
\% / \text { min }\end{array}$ & $\begin{array}{c}\text { M.C } \\
\% \\
(d b)\end{array}$ & $\begin{array}{c}\text { Drying } \\
\text { rate } \\
\% / \text { min }\end{array}$ & $\begin{array}{c}M . C \\
\% \\
(d b)\end{array}$ & $\begin{array}{l}\text { Drying } \\
\text { rate } \\
\% / \text { min }\end{array}$ & $\begin{array}{c}M . C \\
\% \\
(d b)\end{array}$ & $\begin{array}{c}\text { Drying } \\
\text { rate } \\
\% / \text { min }\end{array}$ & $\begin{array}{c}\text { M.C } \\
\% \\
(d b)\end{array}$ \\
\hline 0 & - & 65.00 & - & 58.30 & - & 50.70 & - & 63.4 & - & 56.80 \\
\hline $\begin{array}{l}30 \\
60\end{array}$ & $\begin{array}{c}0.42 \\
0.400\end{array}$ & $\begin{array}{l}52.50 \\
41.70\end{array}$ & $\begin{array}{l}0.523 \\
0.520\end{array}$ & $\begin{array}{l}42.60 \\
31.03\end{array}$ & $\begin{array}{l}0.920 \\
0.900\end{array}$ & $\begin{array}{l}23.10 \\
20.00\end{array}$ & $\begin{array}{l}0.513 \\
0.510\end{array}$ & $\begin{array}{l}48.01 \\
37.10\end{array}$ & $\begin{array}{l}0.560 \\
0.550\end{array}$ & $\begin{array}{l}40.00 \\
27.50\end{array}$ \\
\hline $\begin{array}{c}90 \\
120\end{array}$ & $\begin{array}{l}0.108 \\
0.042\end{array}$ & $\begin{array}{l}32.00 \\
27.00\end{array}$ & $\begin{array}{l}0.071 \\
0.034\end{array}$ & $\begin{array}{l}24.60 \\
20.50\end{array}$ & $\begin{array}{l}0.088 \\
0.034\end{array}$ & $\begin{array}{c}12.09 \\
8.04\end{array}$ & $\begin{array}{l}0.079 \\
0.058\end{array}$ & $\begin{array}{l}30.00 \\
23.00\end{array}$ & $\begin{array}{l}0.083 \\
0.049\end{array}$ & $\begin{array}{l}20.05 \\
14.20\end{array}$ \\
\hline $\begin{array}{l}150 \\
180\end{array}$ & $\begin{array}{l}0.021 \\
0.018\end{array}$ & $\begin{array}{l}24.30 \\
20.60\end{array}$ & $\begin{array}{l}0.025 \\
0.021\end{array}$ & $\begin{array}{l}16.80 \\
13.09\end{array}$ & $\begin{array}{l}0.013 \\
0.012\end{array}$ & $\begin{array}{l}6.30 \\
4.07\end{array}$ & $\begin{array}{l}0.026 \\
0.023\end{array}$ & $\begin{array}{l}19.06 \\
15.00\end{array}$ & $\begin{array}{l}0.028 \\
0.011\end{array}$ & $\begin{array}{l}10.00 \\
8.00\end{array}$ \\
\hline $\begin{array}{l}210 \\
240\end{array}$ & $\begin{array}{c}0.015 \\
0.09\end{array}$ & $\begin{array}{l}19.95 \\
18.01\end{array}$ & $\begin{array}{c}0.015 \\
0.08\end{array}$ & $\begin{array}{c}10.00 \\
8.03\end{array}$ & $\begin{array}{l}0.09 \\
0.08\end{array}$ & $\begin{array}{l}3.30 \\
2.00\end{array}$ & $\begin{array}{l}0.020 \\
0.018\end{array}$ & $\begin{array}{l}13.09 \\
11.08\end{array}$ & $\begin{array}{c}0.010 \\
0.09\end{array}$ & $\begin{array}{l}6.00 \\
5.01\end{array}$ \\
\hline $\begin{array}{l}270 \\
300\end{array}$ & $\begin{array}{l}0.08 \\
0.06\end{array}$ & $\begin{array}{l}16.30 \\
12.00\end{array}$ & $\begin{array}{l}0.07 \\
0.05\end{array}$ & $\begin{array}{l}7.01 \\
6.00\end{array}$ & $\begin{array}{l}0.07 \\
0.06\end{array}$ & $\begin{array}{l}1.54 \\
1.03\end{array}$ & $\begin{array}{l}0.09 \\
0.05\end{array}$ & $\begin{array}{l}9.01 \\
8.00\end{array}$ & $\begin{array}{l}0.07 \\
0.06\end{array}$ & $\begin{array}{l}4.00 \\
3.00\end{array}$ \\
\hline $\begin{array}{l}330 \\
360\end{array}$ & $\begin{array}{l}0.05 \\
0.04\end{array}$ & $\begin{array}{l}9.01 \\
7.06\end{array}$ & $\begin{array}{l}0.04 \\
0.03\end{array}$ & $\begin{array}{l}5.04 \\
4.56\end{array}$ & $\begin{array}{l}0.05 \\
0.04\end{array}$ & $\begin{array}{l}0.99 \\
0.53\end{array}$ & $\begin{array}{l}0.04 \\
0.03\end{array}$ & $\begin{array}{l}6.51 \\
5.17\end{array}$ & $\begin{array}{l}0.05 \\
0.04\end{array}$ & $\begin{array}{l}2.01 \\
1.08\end{array}$ \\
\hline $\begin{array}{l}390 \\
420\end{array}$ & $\begin{array}{l}0.03 \\
0.02\end{array}$ & $\begin{array}{l}5.04 \\
3.08\end{array}$ & $\begin{array}{l}0.02 \\
0.01\end{array}$ & $\begin{array}{l}2.31 \\
1.03\end{array}$ & $\begin{array}{l}0.03 \\
0.02\end{array}$ & $\begin{array}{l}0.08 \\
0.04\end{array}$ & $\begin{array}{l}0.02 \\
0.02\end{array}$ & $\begin{array}{l}3.53 \\
1.50\end{array}$ & $\begin{array}{l}0.03 \\
0.02\end{array}$ & $\begin{array}{l}0.93 \\
0.32\end{array}$ \\
\hline $\begin{array}{c}450 \\
\text { Mean } \pm \text { S.L }\end{array}$ & $\begin{array}{r}0.001 \\
0.21\end{array}$ & $\begin{array}{l}1.07 \\
.33\end{array}$ & $\begin{array}{l}0.01 \\
0.26\end{array}$ & $26^{0.90}$ & $\begin{array}{r}0.001 \\
0\end{array}$ & $\begin{array}{r}0.04 \\
\pm 0.46\end{array}$ & 0.01 & $\begin{array}{r}0.73 \\
\pm 0.36\end{array}$ & 0.01 & $\begin{array}{c}0.32 \\
8 \pm 0.28\end{array}$ \\
\hline
\end{tabular}

Table 3 represents the drying characteristics of yam varieties dried at $33^{\circ} \mathrm{C}$ using sun drying method. It took 2 days to dry the yams to a constant weight. At day 1, white yam recorded a drying rate range of $0.22-0.11 \% / \mathrm{min}$, three leaves recorded $0.19-0.06$ $\% / \mathrm{min}$, purple yam $0.15-0.03 \% / \mathrm{min}$, water yam $0.22-0.07 \% / \mathrm{min}$ and yellow yam had a drying rate range of $0.21-0.08 \% / \mathrm{min}$. At day 2 , the white yam, three leaves yam, purple yam, water yam and yellow yam recorded drying rate range of $0.17-0.01 \% / \mathrm{min}$, $0.18-0.01 \% / \mathrm{min}, 0.14-0.01 \% / \mathrm{min}, 0.20-0.01 \% / \mathrm{min}$ and $0.19-0.001 \% / \mathrm{min}$ respectively. Their average drying rates were $0.11,0.09,0.08,0.11$ and $0.10 \% / \mathrm{min}$ for white yam, three leaves yam, purple, water yam and yellow yam respectively. The standard deviation $( \pm 0.09- \pm 0.16)$ obtained for the drying rate indicated that the values did not deviate much from the mean.

Table 4 represents the moisture ratio of yam varieties dried at $33^{\circ} \mathrm{C}$ using oven drying methods. For all the varieties the drying was completed within 300 mins at air velocity of $1.3 \mathrm{~m} / \mathrm{s}$. White yam had the highest moisture ratio $(0.64-0.02)$ followed by water yam $(0.60-0.08)$, three leaves yam $(0.46-0.01)$, yellow yam $(0.44-0.04)$ and least moisture ratio was observed with purple yam $(0.38-0.02)$. 
Table 4. Moisture ratio of yam varieties dried at $33^{\circ} \mathrm{C}$ using oven drying methods.

\begin{tabular}{cccccc}
\hline $\begin{array}{c}\text { Drying time } \\
\text { (mins) }\end{array}$ & White Yam & Three leaves yam & $\begin{array}{c}\text { Moisture Ratio } \\
\text { Purple yam }\end{array}$ & Water yam & Yellow yam \\
\hline 0.00 & - & - & - & - & - \\
30 & 0.64 & 0.46 & 0.38 & 0.60 & 0.44 \\
60 & 0.32 & 0.24 & 0.16 & 0.28 & 0.20 \\
90 & 0.20 & 0.14 & 0.10 & 0.16 & 0.12 \\
120 & 0.14 & 0.08 & 0.04 & 0.10 & 0.06 \\
150 & 0.10 & 0.07 & 0.02 & 0.08 & 0.04 \\
180 & 0.08 & 0.06 & 0.01 & 0.06 & 0.03 \\
210 & 0.06 & 0.05 & 0.008 & 0.03 & 0.02 \\
240 & 0.04 & 0.04 & 0.006 & 0.02 & 0.01 \\
270 & 0.03 & 0.03 & 0.004 & 0.01 & 0.007 \\
300 & 0.02 & 0.02 & 0.02 & 0.008 & 0.004 \\
Mean & 0.16 & 0.12 & 0.08 & 0.13 & 0.09 \\
\hline
\end{tabular}

Table 5 represents the moisture ratio (M.R) of yam varieties dried at $33^{\circ} \mathrm{C}$ using solar drying method. The white yam, three leaves yam, purple yam, water yam and yellow yam recorded moisture ratios of $0.80-0.04 ; 0.72-0.02,0.68-0.02,0.78-0.02$ and $0.70-0.05$ respectively, at an average air velocity of $1.45 \mathrm{~m} / \mathrm{s}$ and under a total drying time of 480 mins, This agrees with the findings of Jimoh et al. (2010).

Table 5: Moisture ratio of yam varieties dried at $33^{\circ} \mathrm{C}$ using solar drying method

\begin{tabular}{|c|c|c|c|c|c|}
\hline \multirow{2}{*}{$\begin{array}{l}\text { Dryingtime } \\
\text { (mins) }\end{array}$} & \multicolumn{5}{|c|}{ Moisture Ratio } \\
\hline & White Yam & Three leaves yam & Purple yam & Water yam & Yellow yam \\
\hline 0.0 & - & - & - & - & - \\
\hline 30 & 0.80 & 0.72 & 0.68 & 0.78 & 0.70 \\
\hline 60 & 0.70 & 0.58 & 0.48 & 0.66 & 0.48 \\
\hline 90 & 0.60 & 0.45 & 0.26 & 0.52 & 0.34 \\
\hline 120 & 0.51 & 0.34 & 0.16 & 0.42 & 0.22 \\
\hline 180 & 0.36 & 0.18 & 0.07 & 0.26 & 0.10 \\
\hline 240 & 0.30 & 0.11 & 0.06 & 0.18 & 0.09 \\
\hline 300 & 0.14 & 0.06 & 0.05 & 0.10 & 0.08 \\
\hline 360 & 0.08 & 0.04 & 0.04 & 0.04 & 0.07 \\
\hline 420 & 0.06 & 0.03 & 0.03 & 0.03 & 0.06 \\
\hline 480 & 0.04 & 0.02 & 0.02 & 0.02 & 0.05 \\
\hline Mean & 0.36 & 0.25 & 0.19 & 0.30 & 0.22 \\
\hline
\end{tabular}

Table 6. Moisture ratio of yam varieties dried at $33^{\circ} \mathrm{C}$ using sun (open air) drying method (Day 1)

\begin{tabular}{|c|c|c|c|c|c|}
\hline \multirow{2}{*}{$\begin{array}{l}\text { Drying time } \\
\quad \text { (mins) }\end{array}$} & \multicolumn{5}{|c|}{ Moisture Ratio } \\
\hline & White Yam & Three leaves yam & Purple yam & Water yam & Yellow yam \\
\hline Day 1 & - & - & - & - & - \\
\hline 60 & 0.84 & 0.74 & 0.57 & 0.80 & 0.64 \\
\hline 120 & 0.64 & 0.50 & 0.36 & 0.58 & 0.50 \\
\hline 180 & 0.44 & 0.33 & 0.19 & 0.40 & 0.34 \\
\hline 240 & 0.30 & 0.20 & 0.10 & 0.24 & 0.24 \\
\hline 300 & 0.22 & 0.12 & 0.08 & 0.16 & 0.09 \\
\hline 360 & 0.16 & 0.09 & 0.06 & 0.12 & 0.08 \\
\hline 420 & 0.12 & 0.07 & 0.05 & 0.09 & 0.07 \\
\hline 480 & 0.104 & 0.05 & 0.04 & 0.07 & 0.06 \\
\hline 540 & 0.10 & 0.04 & 0.03 & 0.06 & 0.04 \\
\hline Mean & 0.29 & 0.21 & 0.15 & 0.25 & 0.21 \\
\hline
\end{tabular}


Fig 7.Moisture Ratio of five yam varieties dried at $33^{\circ} \mathrm{C}$ using sun (open air) drying method(Day2)

\begin{tabular}{|c|c|c|c|c|c|}
\hline \multirow{2}{*}{$\begin{array}{l}\text { Drying time } \\
\quad(\text { mins })\end{array}$} & \multicolumn{5}{|c|}{ Moisture Ratio } \\
\hline & White Yam & $\begin{array}{l}\text { Three leaves } \\
\text { yam }\end{array}$ & Purple yam & Water yam & Yellow yam \\
\hline Day 2 & 0.10 & 0.08 & 0.04 & 0.09 & 0.08 \\
\hline 60 & 0.05 & 0.03 & 0.03 & 0.045 & 0.04 \\
\hline 120 & 0.03 & 0.01 & 0.02 & 0.02 & 0.02 \\
\hline 180 & 0.012 & 0.009 & 0.008 & 0.01 & 0.01 \\
\hline 240 & 0.01 & 0.008 & 0.007 & 0.007 & 0.009 \\
\hline 300 & 0.007 & 0.006 & 0.006 & 0.005 & 0.008 \\
\hline 360 & 0.006 & 0.005 & 0.005 & 0.004 & 0.007 \\
\hline 420 & 0.004 & 0.003 & 0.004 & 0.003 & 0.006 \\
\hline 480 & 0.003 & 0.002 & 0.003 & 0.002 & 0.005 \\
\hline 540 & 0.002 & 0.001 & 0.002 & 0.001 & 0.003 \\
\hline Mean & 0.02 & 0.02 & 0.02 & 0.02 & 0.02 \\
\hline
\end{tabular}

Tables 6 and 7 represent the moisture ratios of yam varieties dried at $33^{\circ} \mathrm{C}$ using sun (open air) drying method (day 1 and day 2). In day 1 (a) the M.R of the yam varieties varied from 0.84 to $0.10,0.74$ to $0.09 ; 0.57$ to $0.02 ; 0.80$ to 0.06 and 0.64 to 0.04 respectively for white yam, three leaves yam, purple yam, water yam and yellow yam, while in day 2 (b) in the same order, the yam varieties recorded moisture ratios of 0.10 to $0.002,0.08$ to $0.001,0.04$ to $0.002,0.09$ to 0.001 and 0.08 to 0.003 respectively.

The sun (open air) drying method took the highest drying time (540 mins each day) to reduce the moisture content levels of the yam varieties to acceptable limit for milling into flour as compared to oven and solar drying methods.

Figure 1 represents a plot of moisture content against drying time showing an inverse relationship. For every $10 \%$ increase in drying time, the moisture content of the yams dropped by $14 \%$. The yam varieties recorded their highest percentage of moisture removal within the time range of 30 - 90 minutes during which white yam had a moisture content level of $41.50-13.5 \%$ (wb) while three leaves yam, purple yam, water yam, and yellow yam recorded moisture content levels of $32.00-4.50 \%, 36.02-3.08 \%$, $36.30-10.58 \%$ and $29.40-3.22 \%$ (wb) respectively

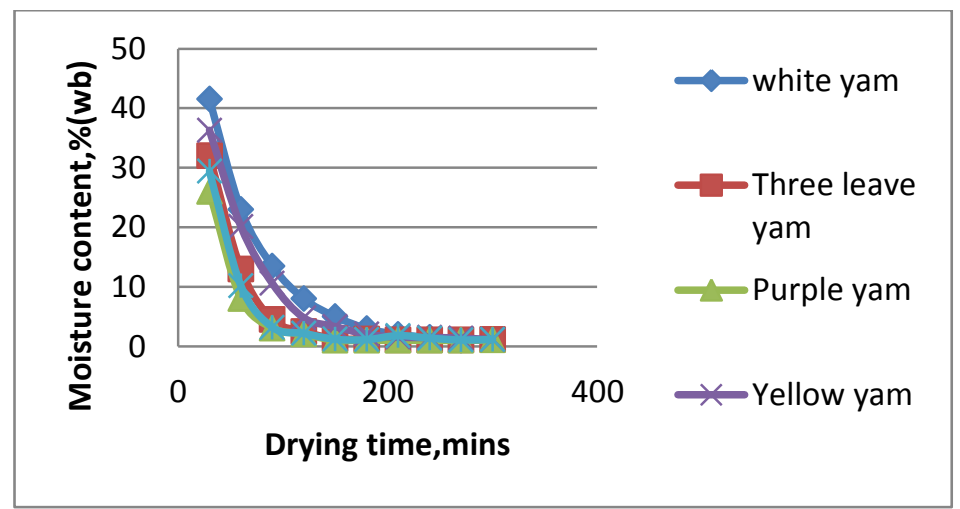

Figure 1: Drying curves of yam varieties at $33^{\circ} \mathrm{C}$ using oven drying method 
Figure 2 represents the effect of drying rate on the moisture contents of the yam varieties. The drying rate showed an initial steep rise, followed by a constant rate, pronounced drop and then the drying rate became slow as time progressed. The curve displayed a short constant drying rate, at which the yam varieties had $0.88 \% / \mathrm{min}$, $0.85 \% / \mathrm{min}, 0.82 \% / \mathrm{min}$, and $0.77 \% / \mathrm{min}$ respectively for yellow yam, water yam, three leaves yam, purple yam and white yam. At these points the moisture content level of the yam varieties ranged from $20-40 \%$ ( wb). Furthermore, the yam varieties registered a falling rate within the moisture content level $(12-20 \%$, wb) and corresponding drying rate $(0.6-0.8 \% / \mathrm{min})$. Following a constant drying rate, the moisture levels of the yams dropped by $20 \%$ with corresponding fall of $17 \%$ in drying rate. This observation agreed favorably with the findings of Ibiyinka et al.(2011)

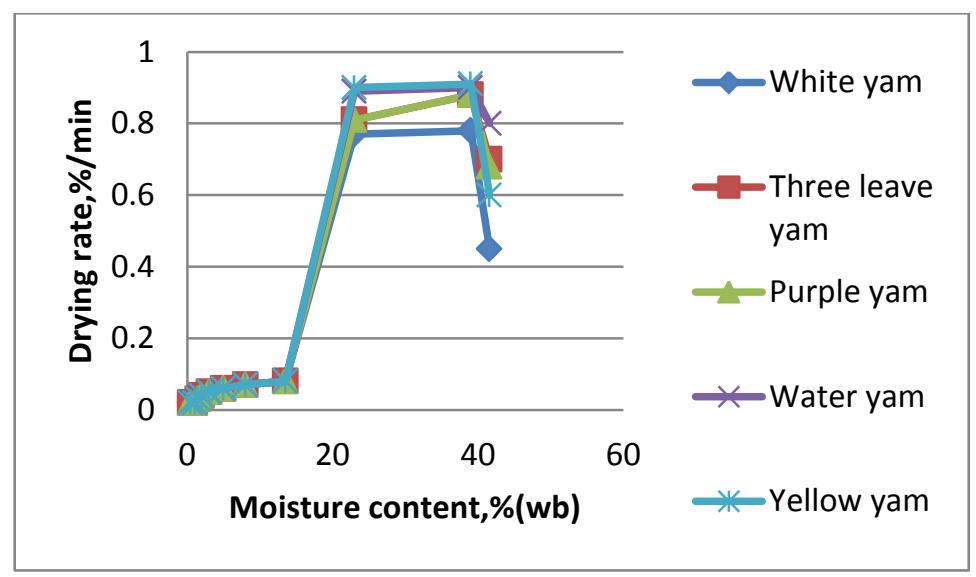

Figure 2: Effect of moisture content on drying rate of yam varieties at $33^{\circ} \mathrm{C}$ using oven drying method.

The effect of drying time on the drying rate of the yam varieties dried with oven drying method at $33^{\circ} \mathrm{C}$.is represented in figure 3. The yams first displayed a short rise in drying rate and then maintained a constant drying rate at range of 0.78 to $0.91 \% / \mathrm{mins}$ with corresponding drying time of 30 - 70mins. Thereafter, there was a fall in the drying rate displayed by the various varieties from $70 \mathrm{mins}$ to about $100 \mathrm{mins}$ and slowly maintained drying rate ranging from 0.05 to $0.01 \% / \mathrm{min}$ within the time range of 120 to 300 mins. After the constant rate, the drying rate of the yams decreased by $20 \%$ for every $25 \%$ increase in the drying time. During the constant rate, yellow yam recorded the highest drying rate of $0.91 \% / \mathrm{min}$ while the white yam recorded the lowest dying rate of $0.78 \% / \mathrm{mins}$. 


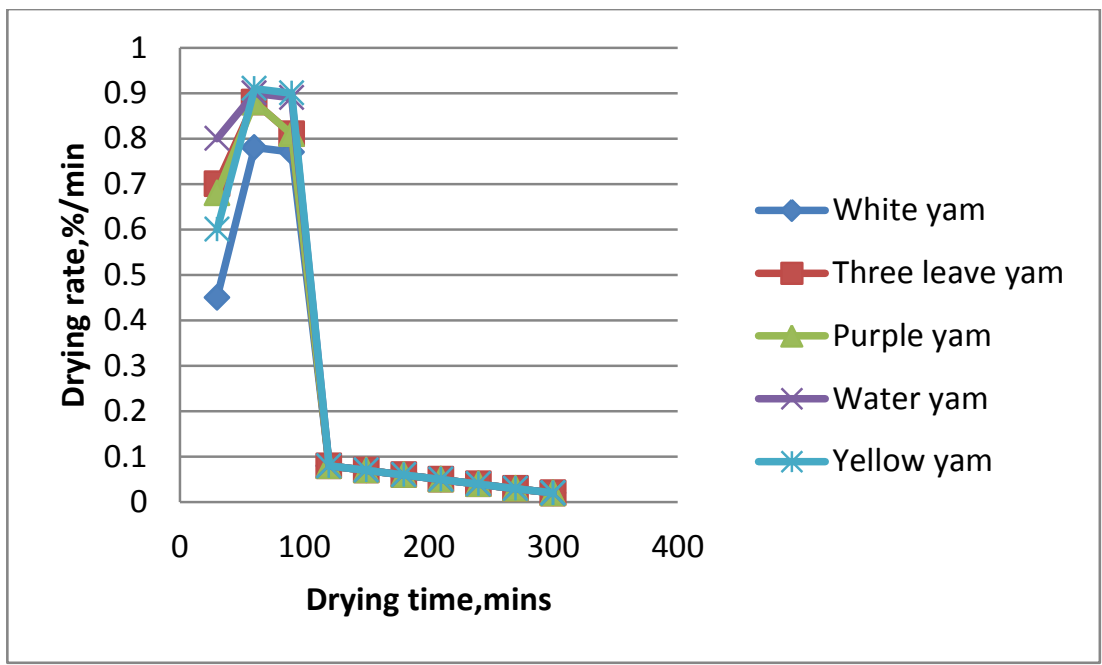

Figure 3. Effect of drying rate on drying time of yam varieties at $33^{\circ} \mathrm{C}$ using oven drying method

Figure 4 represents the drying curves of yam varieties dried at of $33^{\circ} \mathrm{C}$ using solar dryer. The yellow yam and the water yam attained a constant weight at time range of 390 - 420 mins while the white yam, purple and three leaves yam attained the constant weight moisture content at the range of $400-420 \mathrm{mins}$. The standard deviation obtained at $33^{\circ} \mathrm{C}$ ranged from $\pm 0.26- \pm 0.46$ indicating that values did not deviate much from the mean values of the drying rate.

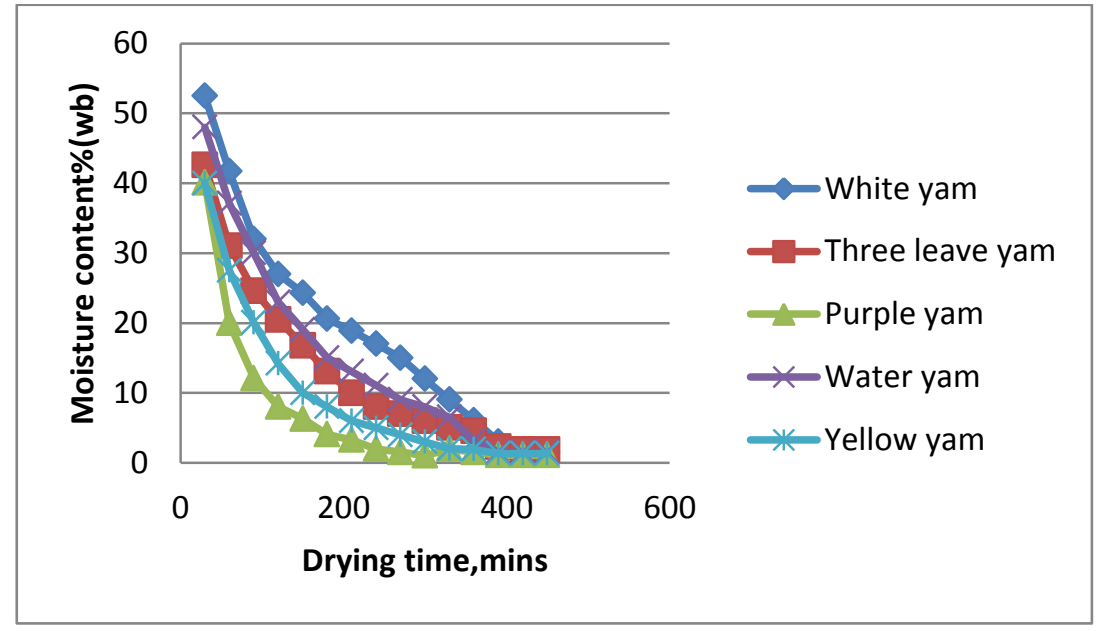

Figure 4. Drying curves of yam varieties dried at $33^{\circ} \mathrm{C}$ using solar dryer

Figure 5 represents the effect of moisture content on drying rate of yam varieties dried at $33^{\circ} \mathrm{C}$ using solar drying method. The constant drying rate of the yam varieties ranged from $0.4-0.9 \% / \mathrm{min}$ and the moisture content level of $40-46 \%$ (wb) with the purple yam having the highest drying rate $(0.9 \% / \mathrm{min})$ at that period. 


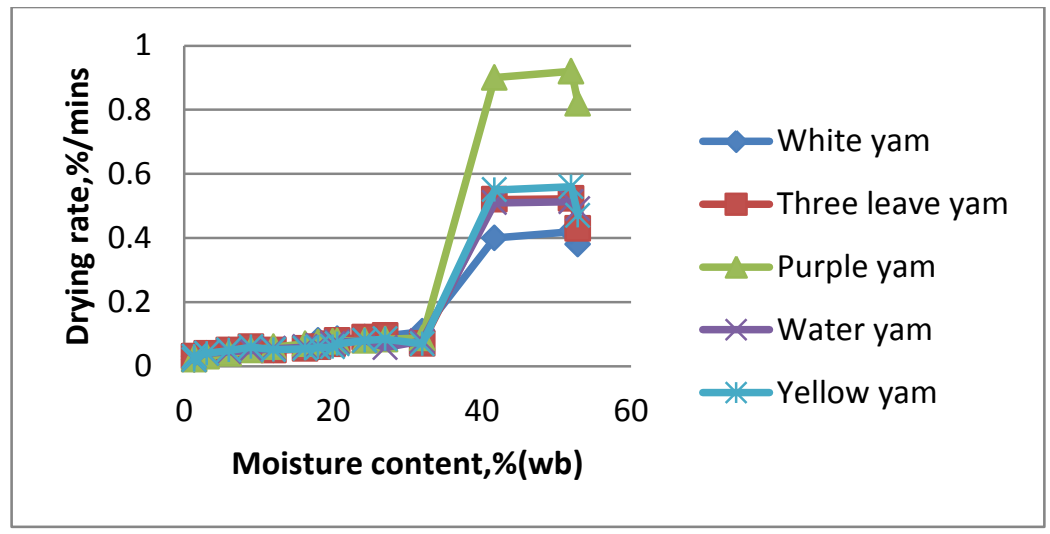

Figure 5. Effect of moisture content on drying rate of yam varieties dried at $33^{\circ} \mathrm{C}$ using solar dryer

Figure 6 represents the effect of drying rate on drying time of five yam varieties dried at $33^{\circ} \mathrm{C}$ using solar drying method. The yam varieties had short constant drying rate of $0.89 \% / \mathrm{min}$ for purple yam, $0.57 \% / \mathrm{min}$ for yellow yam, $0.46 \% / \mathrm{min}$ for three leaves yam, $0.48 \% / \mathrm{min}$ for water yam and $0.41 \% / \mathrm{min}$ for white yam. The corresponding drying time to these drying rates observed for the yam varieties range from $40-70 \mathrm{mins}$. The falling rate for the yam varieties was observed from 43 to 100 mins, and it gradually maintained a very slow drying rate from $0.06-0.01 \% /$ min within the drying time of 130 - 480mins.

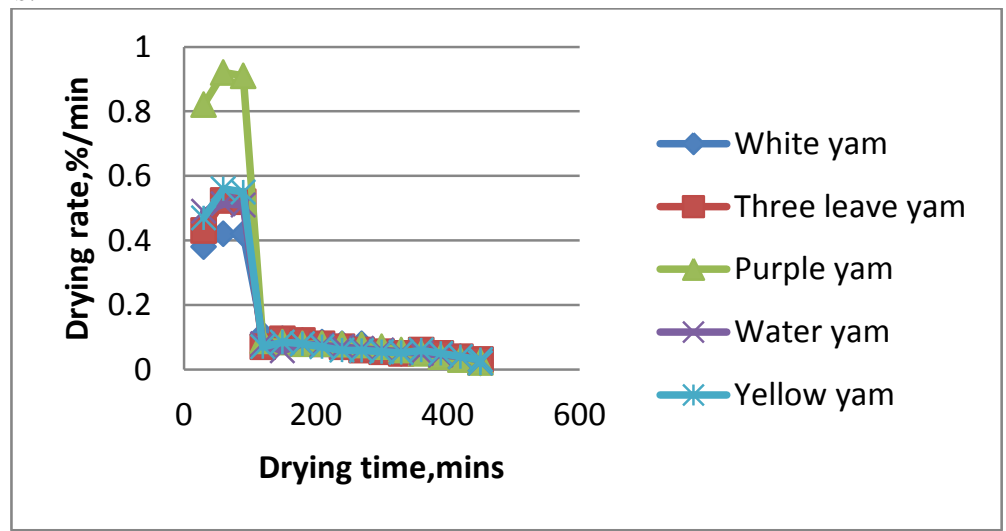

Figure 6. Effect of drying rate on drying time of five varieties of yam dried at temperature of $33^{\circ} \mathrm{C}$ using Solar drying method

Figure (7a and $b$ ) represents the drying curves of yam varieties dried at temperature of $33^{\circ} \mathrm{C}$ using sun dryer for day 1 and 2 at which the drying process was completed. At day 1 the drying stopped at 540 mins leaving moisture content of $24.5 \%(\mathrm{wb})$ for white yam, 21 and $21.5 \%(\mathrm{wb})$ for water yam and three leaves yam respectively; $16 \%$ (wb) for yellow yam and $12 \%$ (wb) for purple yam. At day 2, (Fig 4.3b) the sun drying was completed; each variety attained a constant weight before milling into flour. 


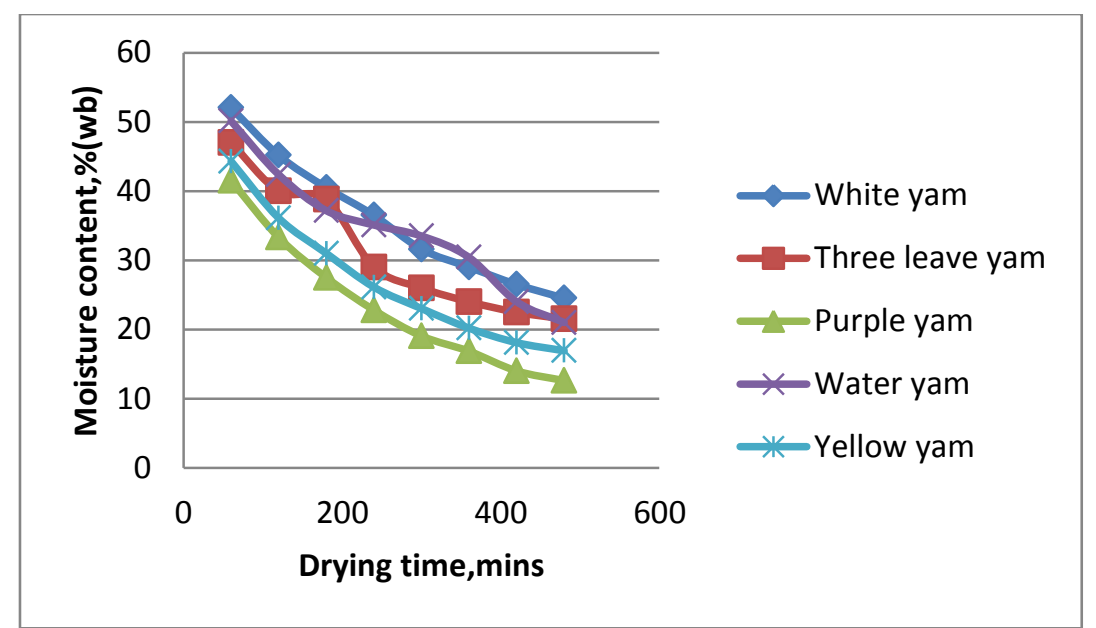

Figure 7a. Drying curves of yam varieties dried at temperature of $33^{\circ} \mathrm{C}$ using sun dryer. (Day 1)

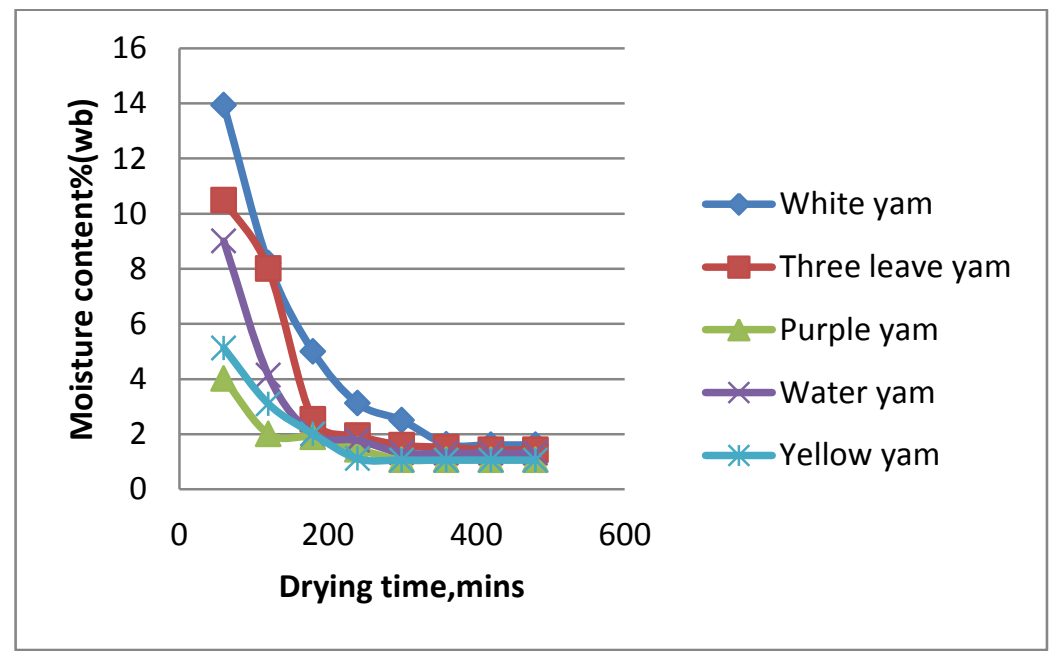

Figure $7 b$. Drying curves of yam varieties dried at $33^{\circ} \mathrm{C}$ using sun dryer (Day2)

The effect of moisture content on drying rate at $33^{\circ} \mathrm{C}$ using sun drying method for day 1 and 2 are represented in figure 8 ( $\mathrm{a}$ and $\mathrm{b}$ ). Like other drying methods the curve followed the same trend. However, the break up in the behaviour of the curve showed on the second day during which the drying process was completed. In day 1 a constant rate for the yam varieties was observed at moisture content range of $45-55 \%(\mathrm{wb})$ with the white yam having constant drying rate of $0.2 \% / \mathrm{min}$, three leaves yam had $0.18 \% / \mathrm{min}$, purple yam $0.15 \% / \mathrm{min}$, water yam $0.23 \% / \mathrm{min}$ and yellow yam $0.21 \% / \mathrm{min}$. The drying was generally completed at day 2 with the yam varieties having a falling rate at 0.9 $14 \%$ (wb) moisture content level. 


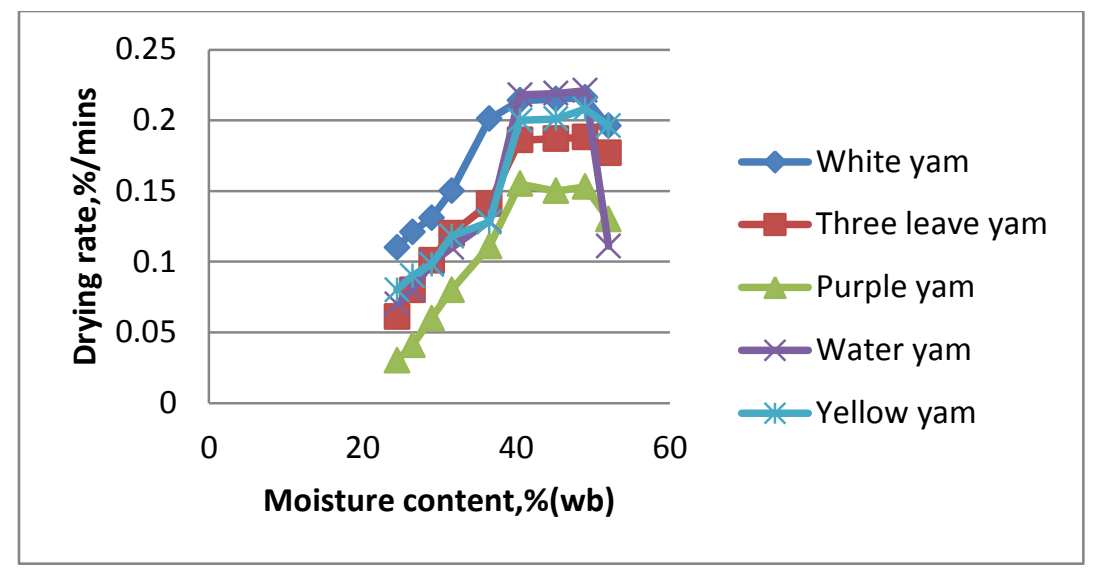

Figure 8a. Effect of moisture content on drying rate at $33^{\circ} \mathrm{C}$ using sun dryer Day 1

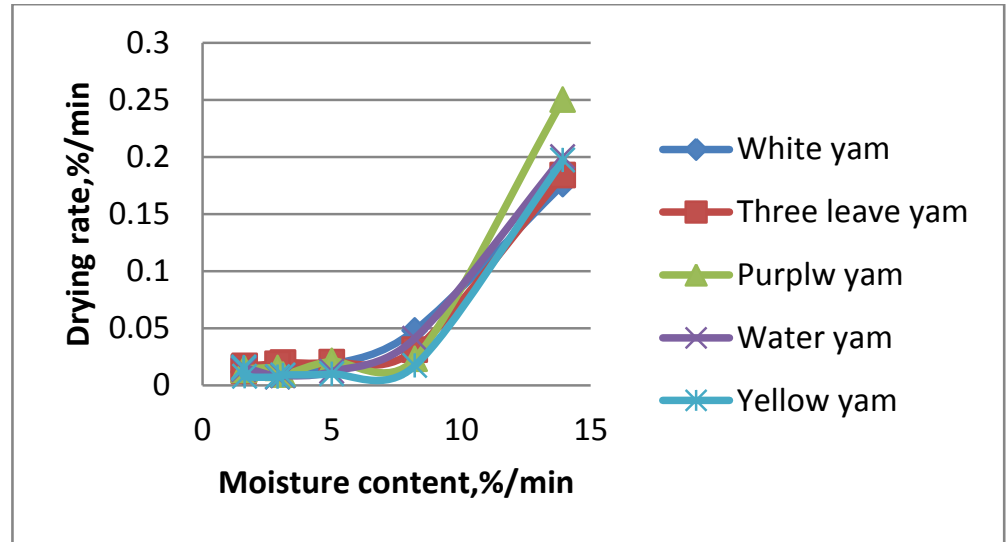

Figure $8 b$. Effect of moisture content on drying rate at $33^{\circ} \mathrm{C}$ using sun drying method Day 2

The effect of drying rate on drying time of five varieties of yam, dried at $33^{\circ} \mathrm{C}$ using Sun (open air) drying method for day 1 and day 2 is represented in Figure 9(a and b). The curves generally followed the same trend like other drying methods. Generally the sun or open air drying method took the highest drying time to attain a constant weight required for milling of the yams into flour. 


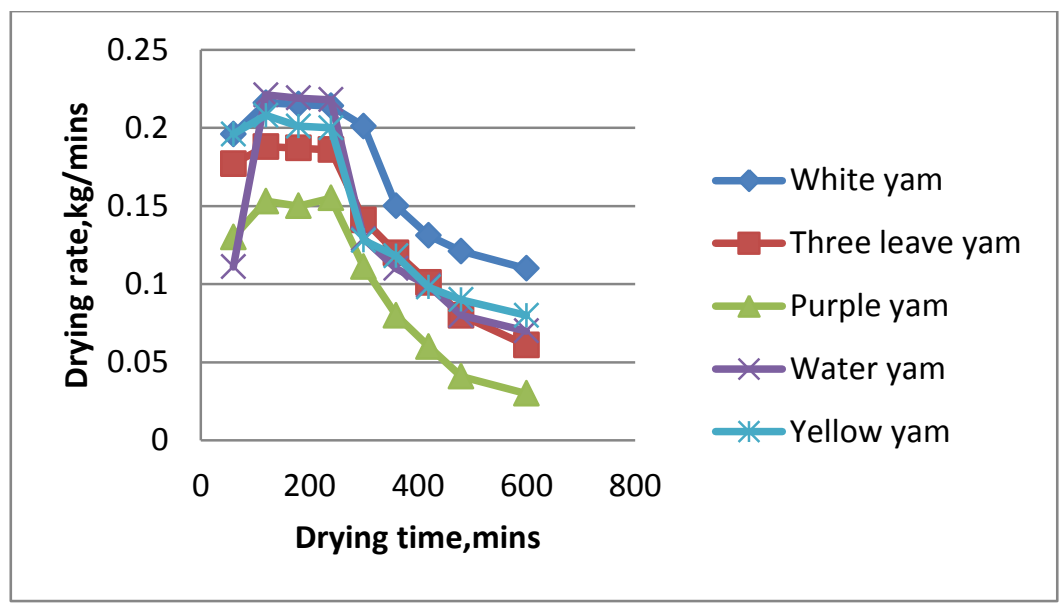

Figure 9a. Effect of drying rate on drying time of five yam varieties dried at $33^{\circ} \mathrm{C}$ using Sun (open air) drying method Dayl

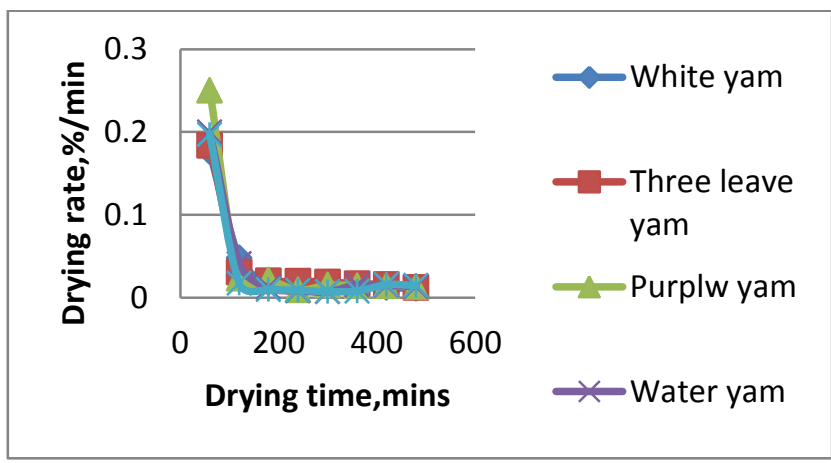

Figure $9 b$ Effect of drying rate on drying time of five yam varieties dried at $33^{\circ} \mathrm{C}$ using Sun (open air) drying method Day2

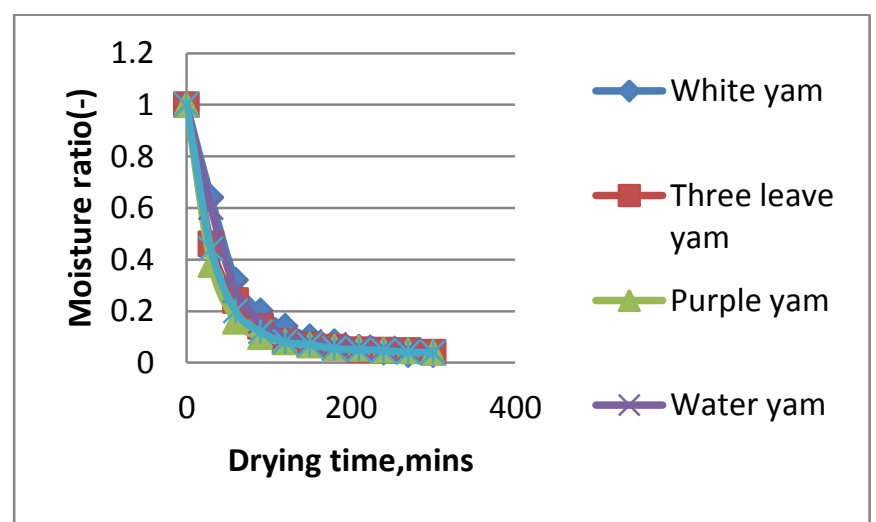

Figure 10: Moisture ratio of yam varieties dried at $33^{\circ} \mathrm{C}$ using oven dryer 
Figure 11 represents the curves of moisture ratio of yam varieties against drying time. The curves also maintained inverse relationship with the drying time in the same manner with the oven drying method. As the drying time increased to $6 \%$ there was $17 \%$ decrease in M.R. The moisture ratio became very slow at about 360 mins of the drying time resulting to $6 \%$ increase in drying time with $5 \%$ decrease in moisture ratio.

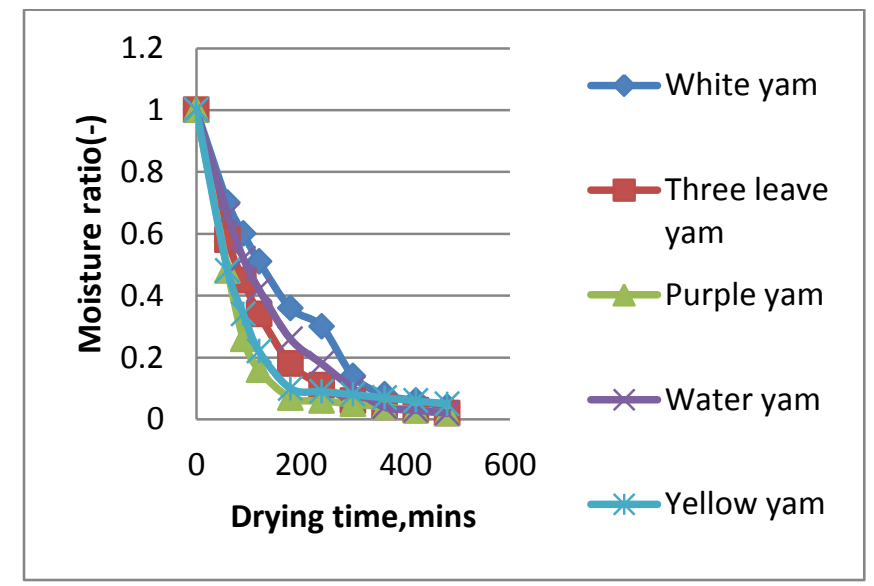

Figure 11. Moisture ratio of yam varieties dried at $33^{\circ} \mathrm{C}$ using solar dryer

Figures 12 and 13 represent graphs of the moisture ratios of yam varieties dried at temperature of $33^{\circ} \mathrm{C}$ using sun (open air) drying method for day 1 and day 2. It took a total drying time of 1008 mins (540mins each day). Like all other varieties, the curves displayed inverse relationship with the M.R; decreasing $2 \%$ with corresponding increase of $7 \%$ in drying time towards the end of the drying. At the beginning it was $7 \%$ increase in drying time resulting to $18 \%$ decrease in moisture ratio.

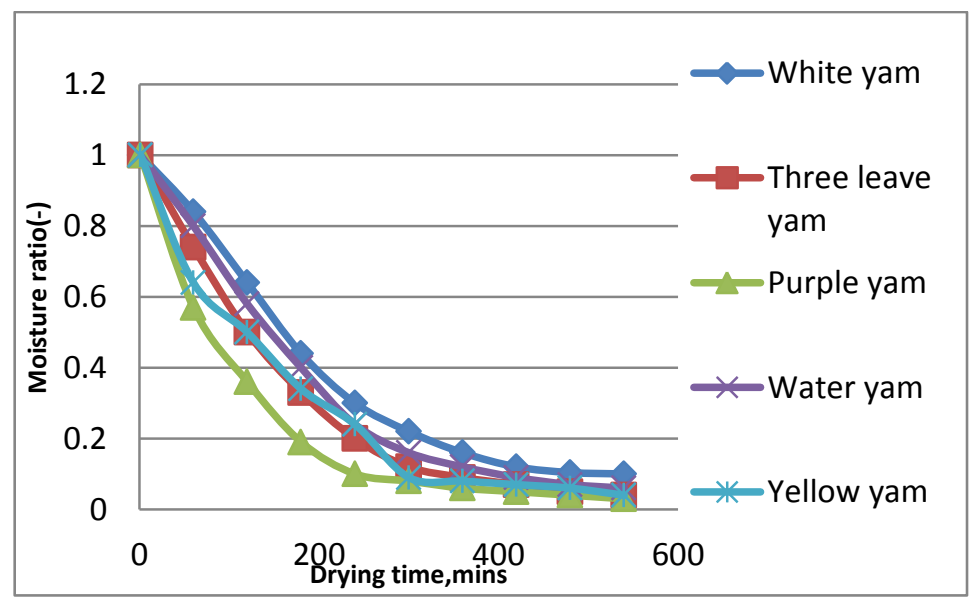

Figure 12. Moisture ratio of yam varieties dried at $33^{\circ} \mathrm{C}$ using sun (open air) drying method (Day 1) 


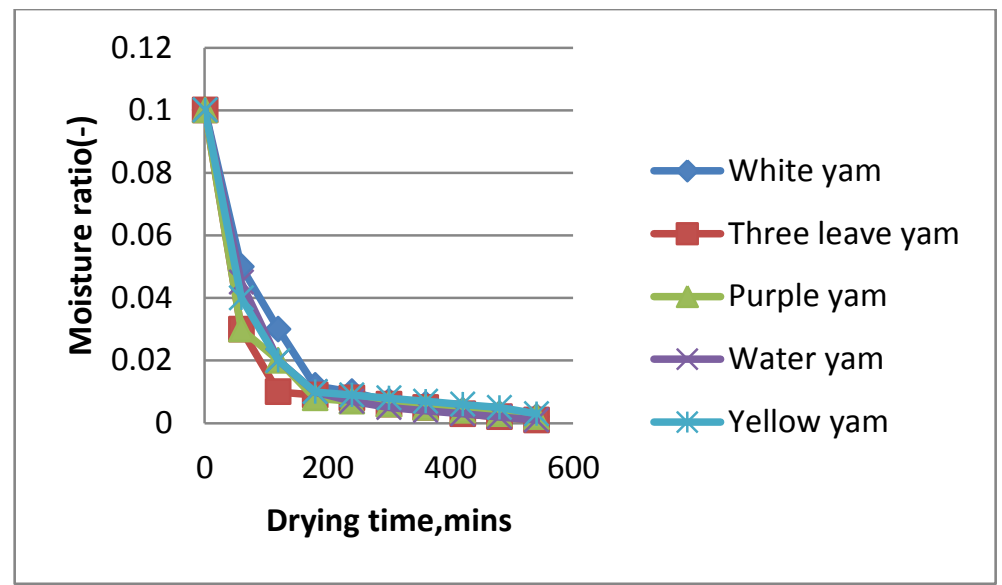

Figure13. Moisture ratio of five yam varieties dried $33^{\circ} \mathrm{C}$ using sun (open air)

\section{CONCLUSIONS}

1. The yam flour varieties attained their constant moisture contents level at different drying times. This variation in drying time may be attributed to the differences in molecular bond and initial moisture content of each of the yam flour varieties.

2. At any giving temperature, the drying rate and moisture content decreased as drying time progressed after the initial constant drying rate and the yam flour varieties showed different behaviours under diverse temperatures and drying methods; a notable point in yam flour drying and in design of yam flour drying equipments.

3. The yam flour varieties recorded drying rate of $0.001-0.95 \mathrm{~kg} / \mathrm{min}$; this can be useful in design of yam drying equipment.

4. The study compared the drying behaviours of different yam flour varieties under different drying methods which will guide engineers in design of yam drying equipment and in understanding of water activities during storage.

\section{REFERENCES}

[1] AACC (2000) Approved Methods of American Association of Cereal Chemists international. The Association, St Paul, MN., USA. 10th Edition. (6) 45- 53.

[2] Africanfoodie (2012) Instant poundo yam production. https://africanfoode. wordpress.com/2012/08/03/instant-pondo-yam

[3] Agwu A. E. and Alu J.I. (2005). Farmers perceived constraints to yam production in Benue State, Nigeria. Proceedings of the $39^{\text {th }}$ Annual conference of the Agricultural society of Nigeria 2005, PP 347 -350.

[4] FAO (2008) Faostat production 2008 data food and Agricultural organization, statistical Division htpp://www.fao.org/doc rep1008/15287e/52860 bihtm 
[5] Ibiyinka .O, Olufunke .O, Olukemi A. Ade .M, Adebayo O. (2011). Effect of Domestic processing on the amino acid profile of Dioscorea rotundata (White yam) African Journal of food science (s)(1) 36-39, 2011.

[6] Iduma F.O., Owombo P.T., U.B. Ighdaro (2014). Economics of yam Production under Agro forestry system in sapoba forest Area, Edo State Nigeria. International Journal of Agriculture and Forestry 2014, 4(6): 440-445.

[7] IITA (2013). International Institute of tropical Agriculture, 4RD review bulletin http://r4drevw.org/2013009/nigeria.release.improve.yamvaritesl

[8] IITA(2008).Research Ginde 55.http://r4drevw.org/2008 004/Nigeria_yam_research_article.

[9] Jimoh, K.O, Olurin, T.O. and Aina J. O. (2010). Effect of drying methods on the rheological characteristics and colour of yam flours. African Journal of Biotechnology 8(10):2325-2328.

[10] Louis Schwaitz (2008). Accessed from www.renewable energy world.com/articles/2008/05/china-fuels-ethanol-industry-with-yams.

[11] Shuaeeb Niyi oyewole and Joshua Olanrewaju Olaoye.(2013). Effect of Drying and blanching parameters on drying rate of "poundo yam" International Journal of Scientific \& Engineering Research Volume 4, Issue 1, January 2013.

[12] Sinjh, U. (2001). Functional properties of grain legume flours. Journal Food Sci. Tech. 38:191-199.

\title{
KARAKTERISTIKE SUŠENJA JAM VARIJETA: KOMPARATIVNA ANALIZA
}

\author{
Chineze G. Okeke ${ }^{1 *}$, B.E. Eje ${ }^{1}$ and P. C. Eze ${ }^{1}$ \\ Department of Agricultural and Bioresource Engineering, Faculty of Engineering, \\ Enugu State University of Science and Technology (ESUT), Enugu, Nigeria
}

Sažetak: Karakteristike sušenja pet Jam (familija Dioscoreaceae, rod Dioscorea) varijeteta: Beli jam, Ljubičasti jam, Trolisni jam, Vodeni jam i Žuti jam) ispitivane su u tri varijante sušenja: elektična sušara, prirodno sušenje na suncu i solarna sušare. Jam krtole (gomolji) su isprane, ručno oguljene, isečene na veličinu debljine od $10 \mathrm{~mm}$. Svaki Jam varijetet je podeljen u tri seta za upotrebu i tri različita postupka sušenja. Sušeni uzorci imaju konstantnu težinu na temperaturi od $33^{\circ} \mathrm{C}$. Sušenje je ponovljeno 6 puta zbog prosečnih rezultata merenja.

U svim metodama sušenja, odnos Jam varijeteta ima razliku vlage u rasponu od 0,21 do $0,08 \%$, a stope sušenja $20 \% / \mathrm{h}-10 \% / \mathrm{h}$ za solarnu sušaru, $16 \% / \mathrm{h}-10,1 \% / \mathrm{h}$ za sušenje u električnoj sušari $23 \% / \mathrm{h}-19,05 \%$ /h za sušenje na suncu. Konstantna težina uzoraka je postignuta od 180 do 300 minuta u uzorcima osušenim u električnoj sušari, 390 do 480 minuta za uzorke osušene u solarnoj sušari, i 780 do 960 minuta za uzorke osušene na suncu. Kod metode sušenja u električnoj sušari Ljubičasti jam se suši brzo (180 min), a zatim Žuti jam (240 min) i Beli jam (300 min).

Sušenje je završeno za dva dana metodom sušenja na suncu, za varijetet Trolisni jam, Ljubičasti i Žuti varijetet jam, koji imaju isto najmanje vreme sušenja, dok Beli i Vodeni Jam imaju isti najduži period sušenja.

\footnotetext{
*Correspondeng author. E-mail address.chinezeglory@yahoo.com
} 
Ključne reči: Jam varijeteti, Sušenje, Metode sušenja, Solarno sušenje, Sunce, Pećnica.

\begin{tabular}{|c|c|}
\hline $\begin{array}{l}\text { Prijavljen: } \\
\text { Submitted: }\end{array}$ & 10.09.2019. \\
\hline $\begin{array}{l}\text { Ispravljen: } \\
\text { Revised: }\end{array}$ & 10.12.2019. \\
\hline $\begin{array}{l}\text { Prihvaćen: } \\
\text { Accepted: }\end{array}$ & 21.01.2020. \\
\hline
\end{tabular}

